\title{
Effect of Transition Elements on the Thermal Stability of Glassy Alloys 82Al-16Fe-2TM (TM: Ti, Ni, Cu) Prepared by Mechanical Alloying
}

\author{
Nguyen Thi Hoang Oanh ${ }^{1}$, , Do Nam Binh ${ }^{1}$, Dung Dang Duc ${ }^{2}$, Quyen Hoang Thi Ngoc ${ }^{1}$ \\ and Nguyen Hoang Viet ${ }^{1, *(\mathbb{D})}$ \\ 1 School of Materials Science and Engineering, Hanoi University of Science and Technology, No 1 Dai Co Viet, \\ Hai Ba Trung, Hanoi 100000, Vietnam; oanh.nguyenthihoang@hust.edu.vn (N.T.H.O.); \\ binhdn@moit.gov.vn (D.N.B.); quyen.hoangthingoc@hust.edu.vn (Q.H.T.N.) \\ 2 School of Engineering Physics, Hanoi University of Science and Technology, No 1 Dai Co Viet, Hai Ba Trung, \\ Hanoi 100000, Vietnam; dung.dangduc@hust.edu.vn \\ * Correspondence: viet.nguyenhoang@hust.edu.vn
}

Citation: Oanh, N.T.H.; Binh, D.N.; Dang Duc, D.; Hoang Thi Ngoc, Q.; Viet, N.H. Effect of Transition

Elements on the Thermal Stability of Glassy Alloys 82Al-16Fe-2TM (TM: Ti, Ni, Cu) Prepared by Mechanical Alloying. Materials 2021, 14, 3978. https://doi.org/10.3390/ma14143978

Academic Editor: Hideki Hosoda

Received: 6 June 2021

Accepted: 12 July 2021

Published: 16 July 2021

Publisher's Note: MDPI stays neutral with regard to jurisdictional claims in published maps and institutional affiliations.

Copyright: (c) 2021 by the authors. Licensee MDPI, Basel, Switzerland. This article is an open access article distributed under the terms and conditions of the Creative Commons Attribution (CC BY) license (https:/ / creativecommons.org/licenses/by/ $4.0 /)$.

\begin{abstract}
In the present study, the thermal stability and crystallization behavior of mechanical alloyed metallic glassy $\mathrm{Al}_{82} \mathrm{Fe}_{16} \mathrm{Ti}_{2}, \mathrm{Al}_{82} \mathrm{Fe}_{16} \mathrm{Ni}_{2}$, and $\mathrm{Al}_{82} \mathrm{Fe}_{16} \mathrm{Cu}_{2}$ were investigated. The microstructure of the milled powders was characterized by scanning electron microscopy (SEM), X-ray diffraction (XRD), and differential scanning calorimetry (DSC). The results showed remarkable distinction in thermal stability of the alloys by varying only two atomic percentages of transition elements. Among them, $\mathrm{Al}_{82} \mathrm{Fe}_{16} \mathrm{Ti}_{2}$ alloy shows the highest thermal stability compared to the others. In the crystallization process, exothermal peaks corresponding to precipitation of fcc-Al and intermetallic phases from amorphous matrix were observed.
\end{abstract}

Keywords: Al-based amorphous alloy; thermal stability; mechanical alloying; solid-state transformations

\section{Introduction}

It is widely known that metallic glasses are novel engineering alloys, which exhibited properties that were different from conventional crystalline materials. The unique properties of metallic glass were originally derived from the random atomic arrangement of metallic glasses [1-4]. Owing to the absence of grain boundaries and crystal defects typically found in crystalline materials, amorphous alloys exhibit excellent mechanical properties. The tensile strength of melt-spun Al-ETM-LTM amorphous ribbons exceeded $1200 \mathrm{MPa}$ [5] (early transition metal (ETM), late transition metal (LTM)), which was approximately three times that of conventional aluminum alloys [2]. The Al-based metallic glasses have a great potential application in the automotive industry, aerospace and military fields, requiring high corrosion resistance, high strength, and a high-specificity elastic modulus [6]. Among the aluminum alloys, iron aluminides containing more than $80 \%$ $\mathrm{Al}$ are promising candidates for structural applications due to high specific strength and excellent corrosion resistance at elevated temperatures under oxidizing, carburizing, and sulfurizing atmospheres [7]. The addition of Fe in an Al matrix by mechanical alloying technique results in a super-saturated solution formation during the milling process and in amorphous Al-Fe alloys in final production [6]. Normally, metallic glasses are metastable materials at room temperature. Under a suitable heating process, the atoms rearrange to form crystalline or quasicrystalline phases [1,4,8-10]. The crystallization behavior of Al-Ni-La ternary [11] and Al-Fe-Ni-La quaternary [12] systems indicated a three-stage process with primary crystallization of the fcc-Al. It has been noticed that the homogeneous dispersion of nanocrystalline $\mathrm{fcc}-\mathrm{Al}$ particles in the residual amorphous matrix increase in tensile strength up to $1560 \mathrm{MPa}$, as reported in [13]. Despite the remarkable 
improvement of tensile strength of the amorphous materials, the limited ductility can be incorporated into the amorphous matrix through the dispersion of nanometric phases $[4,9,14]$. $\mathrm{N}$. Bassim et al. [15] studied the crystallization behavior and microstructure development upon annealing amorphous melt-spun ribbons $\mathrm{Al}_{84} \mathrm{Y}_{9} \mathrm{Ni}_{5} \mathrm{Co}_{2}$. The crystallization onset temperature of this alloy, at a heating rate of $20 \mathrm{~K} / \mathrm{min}$, was $292{ }^{\circ} \mathrm{C}$. J. Q. Wang et al. [16] investigated the crystallization behavior of as-quenched $\mathrm{Al}_{88} \mathrm{Ni}_{9} \mathrm{Ce}_{2} \mathrm{Fe}_{1}$ melt-spun ribbons. The first crystallization reaction with precipitation of nanocrystals had an onset temperature of $155.2{ }^{\circ} \mathrm{C}$. Additionally, Viet et al. [17] studied the crystallization kinetics of $\mathrm{Al}-\mathrm{Fe}$ and $\mathrm{Al}-\mathrm{Fe}-\mathrm{Y}$ amorphous alloys synthesized by mechanical alloying. It was reported that the crystallization onset temperatures can be increased with an increase in the Fe content and substitution of $\mathrm{Y}$ for Al. However, only a few works have studied the thermal stability and crystallization behavior of the Al-Fe-TM (transition metal (TM)) alloys prepared by mechanical alloying (MA) to date. Some practical techniques synthesize amorphous alloys with metastable equilibrium microstructures, such as mechanical alloying (MA), melt spinning, gas atomization, and rapid quenching techniques [4,9,18-24]. Among them, MA is a versatile method owing to its simplicity and ease of synthesis. The MA products are produced in powder form, which is very helpful for the sintering process. In addition, MA also extends solid solubility in many binary systems, which are normally immiscible in the solid state or even in the liquid state [9,25-27].

In this work, the thermal stability of metallic glasses alloys with a nominal composition of $\mathrm{Al}_{82} \mathrm{Fe}_{16} \mathrm{Ti}_{2}, \mathrm{Al}_{82} \mathrm{Fe}_{16} \mathrm{Ni}_{2}$, and $\mathrm{Al}_{82} \mathrm{Fe}_{16} \mathrm{Cu}_{2}$ prepared by mechanical alloying is investigated. The effect of minor alloying additions $(\mathrm{Ti}, \mathrm{Ni}, \mathrm{Cu})$ on crystallization and thermal stability of Al-Fe alloys is also examined.

\section{Materials and Methods}

82Al-16Fe-2TM (TM: Ti, Ni, Cu) amorphous alloy powders were prepared by mechanical alloying from elemental blend powders in a Fritsch Pulverisette-6 (Fritsch, IdarOberstein, Germany) planetary ball mill at a rotation rate of $300 \mathrm{rpm}$, according to our previous work [28]. Hardened steel balls were used at a 20:1 ball to powder weight ratio. Stainless steel vials were used to contain the powder and milling balls, and $50 \mathrm{~mL}$ of $\mathrm{n}$-hexane was added as a control agent to prevent sticking phenomena. Before milling, the vials were sealed and evacuated. The milling processes were interrupted every $30 \mathrm{~min}$ to prevent excessive heating. In order to investigate the thermal stability, three alloy powders, after milling for 10, 40,50, and $60 \mathrm{~h}$ in amorphous state, corresponding to $\mathrm{Al}_{82} \mathrm{Fe}_{16} \mathrm{Ti}_{2}$, $\mathrm{Al}_{82} \mathrm{Fe}_{16} \mathrm{Ni}_{2}$, and $\mathrm{Al}_{82} \mathrm{Fe}_{16} \mathrm{Cu}_{2}$, respectively, were chosen.

The morphology of milled powders was characterized by field-emission scanning electron microscopy (FE-SEM) using a JEOL JSM-7600F (JEOL Ltd., Tokyo, Japan). Phase analysis was done by X-ray diffraction (XRD) in a SIEMENS D5000 diffractometer (Siemens, Berlin, Germany) using $\mathrm{Cu} K \alpha$ radiation $(\lambda=1.5405 \AA$ ). The XRD parameters were: $2 \theta$ range of 20 to $80^{\circ}$; a step size of $0.03^{\circ}$; scanning speed $1^{\circ}$ per min. Particle size distribution of amorphous powders was tested by the Laser Scattering Particle Size Distribution Analyzer LA-960 (Horiba Ltd., Kyoto, Japan). The MDI Jade version 6.5 (associated with the ICDD PDF2 database, 2007, Newtown Square, PA, USA) was used for the peaks matching the reference sample. The refined lattice parameters of crystallization phases were evaluated via Profex (version 4.3.2a, released 30 March 2021, Solothurn, Switzerland), a graphical user interface for Rietveld refinement of powder X-ray diffraction data with the program BGMN [29]. The thermal stability of as-milled powders was studied by differential scanning calorimetry (DSC) in a Netzsch STA 449C-QMS 403C Thermal Analyzer System (Netzsch Gerätebau GmbH, Selb, Germany). The non-isothermal DSC studies were carried out at a heating rate of $20 \mathrm{~K} / \mathrm{min}$ under a continuous flow of purified argon gas flow. Specimens after heating in the calorimeter were investigated by XRD. 


\section{Results}

Figure 1 shows the FE-SEM micrographs of mechanically alloyed powders, $\mathrm{Al}_{82} \mathrm{Fe}_{16} \mathrm{Ti}_{2}$, $\mathrm{Al}_{82} \mathrm{Fe}_{16} \mathrm{Ni}_{2}$, and $\mathrm{Al}_{82} \mathrm{Fe}_{16} \mathrm{Cu}_{2}$, after 40, 50, and $60 \mathrm{~h}$ of milling, respectively. In two alloys, $\mathrm{Al}_{82} \mathrm{Fe}_{16} \mathrm{Ti}_{2}$ and $\mathrm{Al}_{82} \mathrm{Fe}_{16} \mathrm{Ni}_{2}$, the particle size was about 2 to $3 \mu \mathrm{m}$ under the SEM observation. Most particles were flattened because of the collision between powders, balls, and jar. The powder particles had a layered structure due to the repeated fracture and welding processes during the milling process. The agglomerate of small powder particles can be seen in Figure $1 \mathrm{a}, \mathrm{b}$. In the $\mathrm{Al}_{82} \mathrm{Fe}_{16} \mathrm{Cu}_{2}$ alloy, the particle size of powder was in the range of 2-10 $\mu \mathrm{m}$, which implies that the welding process was more dominant. As reported in [28], $\mathrm{Al}_{82} \mathrm{Fe}_{16} \mathrm{Ti}_{2}$ and $\mathrm{Al}_{82} \mathrm{Fe}_{16} \mathrm{Ni}_{2}$ alloys are fully amorphous structures after milling for 40 and $50 \mathrm{~h}$, respectively. In $\mathrm{Al}_{82} \mathrm{Fe}_{16} \mathrm{Cu}_{2}$ powder, only partly amorphous structure was obtained even after milling for a longer time of $60 \mathrm{~h}$. Particle size distribution curves of amorphous alloy samples were measured by means of laser light scattering granulometry, as shown in Figure 2. Two samples exhibited a unimodal distribution and an average particle size, $\mathrm{d}_{0.5}$, of 15.9 and $9.4 \mu \mathrm{m}$ for $\mathrm{Al}_{82} \mathrm{Fe}_{16} \mathrm{Ti}_{2}$ and $\mathrm{Al}_{82} \mathrm{Fe}_{16} \mathrm{Ni}_{2}$ powders after 40 and $50 \mathrm{~h}$ of milling, respectively. Meanwhile, the $\mathrm{Al}_{82} \mathrm{Fe}_{16} \mathrm{Cu}_{2}$ alloy sample exhibited a bimodal distribution and an average particle size, $\mathrm{d}_{0.5}$, of $14.6 \mu \mathrm{m}$. Figure $2 \mathrm{~d}$ compares the cumulative size distribution curve of three alloy powders. While the particle size distribution of $\mathrm{Al}_{82} \mathrm{Fe}_{16} \mathrm{Ni}_{2}$ and $\mathrm{Al}_{82} \mathrm{Fe}_{16} \mathrm{Cu}_{2}$ remained nearly the same in the lower size range, the cumulative size distribution curve of $\mathrm{Al}_{82} \mathrm{Fe}_{16} \mathrm{Ti}_{2}$ shifted rightwards, indicating that particle size shifted to a larger micron range $(<30 \mu \mathrm{m}$ at $90 \%$ volume fraction).
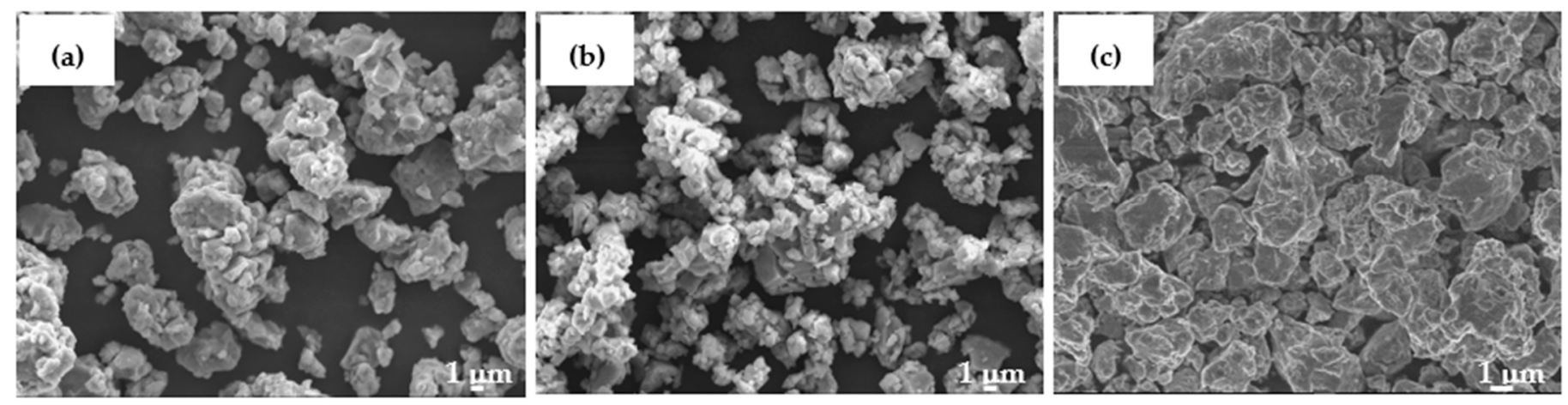

Figure 1. FE-SEM micrographs of (a) $\mathrm{Al}_{82} \mathrm{Fe}_{16} \mathrm{Ti}_{2}$, (b) $\mathrm{Al}_{82} \mathrm{Fe}_{16} \mathrm{Ni}_{2}$, and (c) $\mathrm{Al}_{82} \mathrm{Fe}_{16} \mathrm{Cu}_{2}$ powders after 40, 50, and 60 h of milling, respectively.

Table 1 listed atomic radii mismatch (in \%) and enthalpies of mixing (in $\mathrm{kJ} / \mathrm{mole}$ ) for $\mathrm{Al}, \mathrm{Fe}, \mathrm{Ni}, \mathrm{Ti}, \mathrm{Cu}, \mathrm{Y}$, and La binary systems, according to [30,31]. The three basic empirical rules, for the achievement of high glass-forming ability, are: (1) the alloy must contain at least three components; (2) a significant atomic size difference among the main constituent elements in the alloy should be above $12 \%$; (3) there should be a negative heat of mixing among the major constituent elements in the alloy system [32,33]. The three rules played an important role in the selection of elements for bulk metallic glasses containing rare-earth alloys fabricated by rapid quenching technique. However, there are cases where those rules do not apply, namely for metallic glass alloys containing rare-earth elements and produced by mechanical alloying, such as $\mathrm{Al}_{82} \mathrm{Fe}_{16} \mathrm{Y}_{2}$ and $\mathrm{Al}_{82} \mathrm{Fe}_{4} \mathrm{Ni}_{4} \mathrm{La}_{10}$ systems. $\mathrm{Y}$ and $\mathrm{La}$ have quite large atomic sizes, and the atomic mismatches of Al-Y and Al-La are about 21.4 and $23.9 \%$, respectively. These alloys achieved a fully amorphous structure for a long time of milling at 100 and $350 \mathrm{~h}$, respectively [12,17]. In contrast, the amorphization of $\mathrm{Al}-\mathrm{Fe}$ alloys without rare-earth elements, such as $\mathrm{Al}_{82} \mathrm{Fe}_{16} \mathrm{Ti}_{2}, \mathrm{Al}_{82} \mathrm{Fe}_{16} \mathrm{Ni}_{2}$, and $\mathrm{Al}_{82} \mathrm{Fe}_{16} \mathrm{Cu}_{2}$, occurs after shorter milling periods [28]. It is evident that the atomic mismatch does not significantly influence the glass-forming ability (GFA) in Al-Fe alloys produced by the mechanical alloying technique because of the nearly similar atomic size of $\mathrm{Ti}, \mathrm{Ni}$, and $\mathrm{Cu}$ transition elements. However, the amorphization process varied with the mixing enthalpy 
values of transition elements. This could be due to the values of the different mixing enthalpy of different alloying elements in ascending orders: $\mathrm{Al}-\mathrm{Ti}<\mathrm{Al}-\mathrm{Ni}<\mathrm{Al}-\mathrm{Cu}$, as well as $\mathrm{Fe}-\mathrm{Ti}<\mathrm{Fe}-\mathrm{Ni}<\mathrm{Fe}-\mathrm{Cu}$. There is a tendency for glass formation to increase with decreasing mixing enthalpy. The $\mathrm{Al}_{82} \mathrm{Fe}_{16} \mathrm{Ti}_{2}$ alloy presented the most negative mixing enthalpy with all binary elements, while $\mathrm{Ni}$ has a small negative value of mixing enthalpy with $\mathrm{Fe}$, and $\mathrm{Cu}$ showed a positive enthalpy of mixing with $\mathrm{Fe}$. The values of mixing enthalpy may be decisive in the amorphization process.

(a)

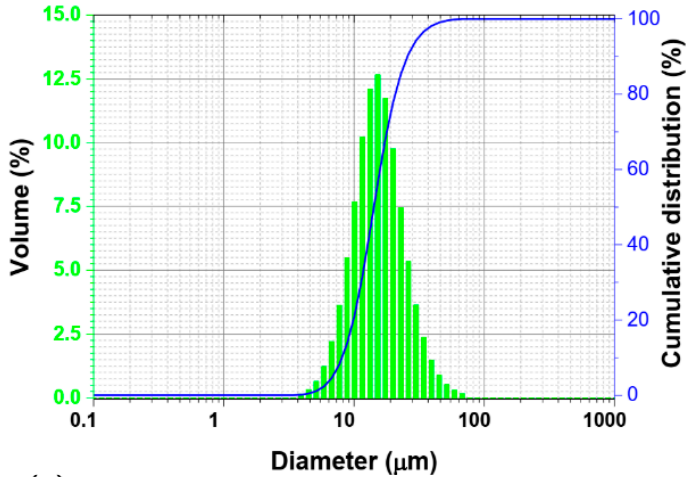

(c)

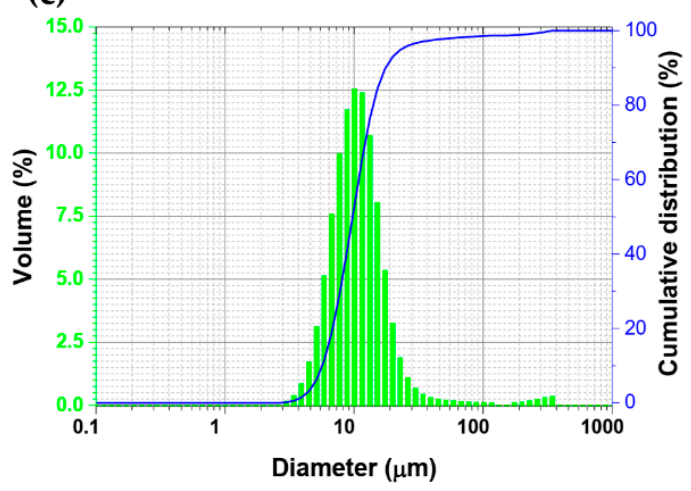

(b)

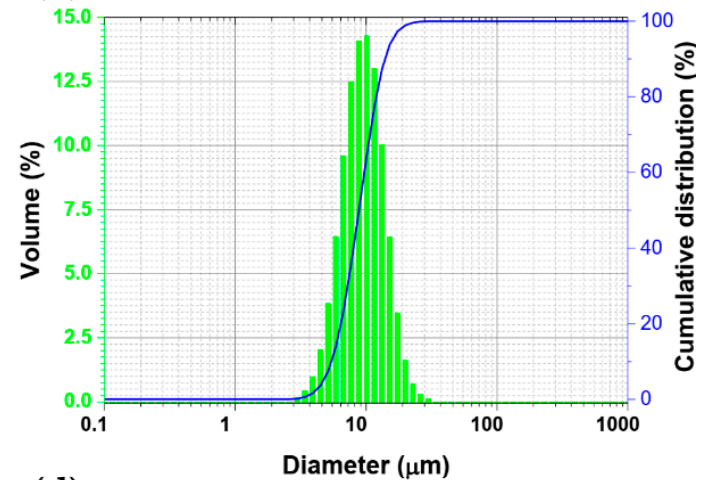

(d)

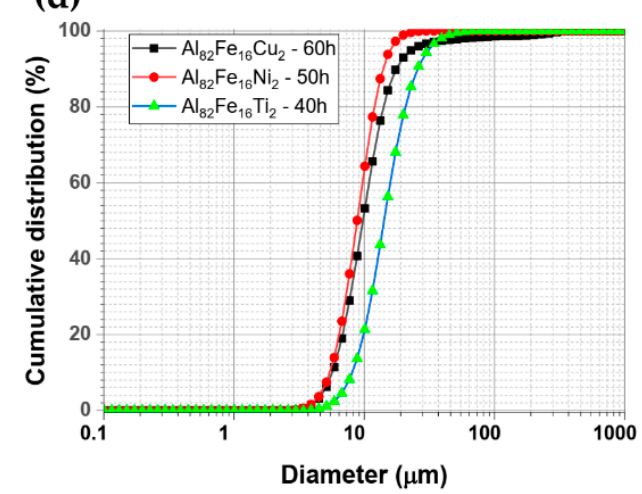

Figure 2. Particle size distribution of (a) $\mathrm{Al}_{82} \mathrm{Fe}_{16} \mathrm{Ti}_{2}$, (b) $\mathrm{Al}_{82} \mathrm{Fe}_{16} \mathrm{Ni}_{2}$, and (c) $\mathrm{Al}_{82} \mathrm{Fe}_{16} \mathrm{Cu}_{2}$ powders after 40, 50, and 60 h of milling, respectively; (d) cumulative distribution of three alloy powders.

Table 1. Atomic radii mismatch (in \%) and enthalpies of mixing (in $\mathrm{kJ} /$ mole) for $\mathrm{Al}, \mathrm{Fe}, \mathrm{Ni}, \mathrm{Ti}, \mathrm{Cu}, \mathrm{Y}, \mathrm{and} \mathrm{La}$ binary systems [30].

\begin{tabular}{|c|c|c|c|c|c|c|c|}
\hline Element & Al & $\mathrm{Fe}$ & $\mathrm{Ti}$ & $\mathrm{Ni}$ & $\mathrm{Cu}$ & $\mathbf{Y}$ & La \\
\hline Al & - & $13(\%)$ & 2.7 (\%) & $12.5(\%)$ & $10(\%)$ & $21.4(\%)$ & $23.9(\%)$ \\
\hline $\mathrm{Fe}$ & $-11(\mathrm{~kJ} /$ mole $)$ & - & $15.6(\%)$ & $0.8(\%)$ & $3.1(\%)$ & $31.8(\%)$ & $34(\%)$ \\
\hline $\mathrm{Ti}$ & $-30(\mathrm{~kJ} / \mathrm{mole})$ & $\begin{array}{c}-17 \\
(\mathrm{~kJ} / \text { mole })\end{array}$ & 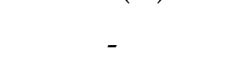 & $14.9(\%)$ & $12.9(\%)$ & $19.2(\%)$ & $21.8(\%)$ \\
\hline $\mathbf{N i}$ & $-22(\mathrm{~kJ} / \mathrm{mole})$ & $-2(\mathrm{~kJ} / \mathrm{mole})$ & $-35(\mathrm{~kJ} /$ mole $)$ & - & $2.3(\%)$ & $31.3(\%)$ & $33(\%)$ \\
\hline $\mathrm{Cu}$ & $-1(\mathrm{~kJ} / \mathrm{mole})$ & $+4(\mathrm{~kJ} /$ mole $)$ & $-9(\mathrm{~kJ} / \mathrm{mole})$ & $+4(\mathrm{~kJ} / \mathrm{mole})$ & - & $29.6(\%)$ & $31.9(\%)$ \\
\hline $\mathrm{Y}$ & $-38(\mathrm{~kJ} /$ mole $)$ & $-1(\mathrm{~kJ} / \mathrm{mole})$ & $+15(\mathrm{~kJ} /$ mole $)$ & $-31(\mathrm{~kJ} / \mathrm{mole})$ & $-22(\mathrm{~kJ} / \mathrm{mole})$ & - & $3(\%)$ \\
\hline La & $-38(\mathrm{~kJ} / \mathrm{mole})$ & $+5(\mathrm{~kJ} / \mathrm{mole})$ & $+20(\mathrm{~kJ} /$ mole $)$ & $-27(\mathrm{~kJ} / \mathrm{mole})$ & $-21(\mathrm{~kJ} /$ mole $)$ & $+20(\mathrm{~kJ} / \mathrm{mole})$ & - \\
\hline
\end{tabular}

In order to investigate the thermal stability of the as-milled powders, a non-isothermal DSC mode was applied. Figure $3 a-c$ presented the DSC curves of milled powders after $10 \mathrm{~h}$ and amorphous states of milling, respectively. Characteristic temperatures, $\mathrm{T}_{\mathrm{x}}$ and $\mathrm{T}_{\mathrm{p}}$ (onset and maximum of the crystallization exothermal peak, respectively), were obtained from DSC scans of powdered samples heated at a constant heating rate of $20 \mathrm{~K} \cdot \mathrm{min}^{-1}$. Most DSC curves of three alloy powders milled at different times exhibited three exothermic peaks, except $\mathrm{Al}_{82} \mathrm{Fe}_{16} \mathrm{Cu}_{2}$ alloy powders milled for $10 \mathrm{~h}$. The calorimetric curve recorded 
for this alloy presented only one peak at a temperature of about $320-420{ }^{\circ} \mathrm{C}$. From the XRD patterns of powders milled for $10 \mathrm{~h}$, there was a small broad diffuse halo of an amorphous phase together with sharpness diffraction peaks corresponding to the existence of minor volume fractions of unprocessed nanoparticles in a scattering range of $2 \theta$ between $40-50^{\circ}$, as presented in our previous work [28]. These nanoparticles reacted with each other to produce intermetallic phases, resulting in lower onset crystallization temperatures of three alloys. The onset temperature of amorphous $\mathrm{Al}_{82} \mathrm{Fe}_{16} \mathrm{Ti}_{2}, \mathrm{Al}_{82} \mathrm{Fe}_{16} \mathrm{Ni}_{2}$, and $\mathrm{Al}_{82} \mathrm{Fe}_{16} \mathrm{Cu}_{2}$ alloys after milling for 40,50 , and $60 \mathrm{~h}$ starts at 398,365 , and $334^{\circ} \mathrm{C}$, respectively. The $\mathrm{Al}_{82} \mathrm{Fe}_{16} \mathrm{Ti}_{2}$ alloy had the highest onset crystallization temperature, and the $\mathrm{Al}_{82} \mathrm{Fe}_{16} \mathrm{Cu}_{2}$ alloy had the lowest onset temperature. This DSC profile was similar to the one reported in the literature for $\mathrm{Al}_{82} \mathrm{Fe}_{18}$ and $\mathrm{Al}_{82} \mathrm{Fe}_{16} \mathrm{Y}_{2}$ alloy [34], where the peaks are related to the exothermic effects connected with fcc-Al and intermetallic phases.

(a)

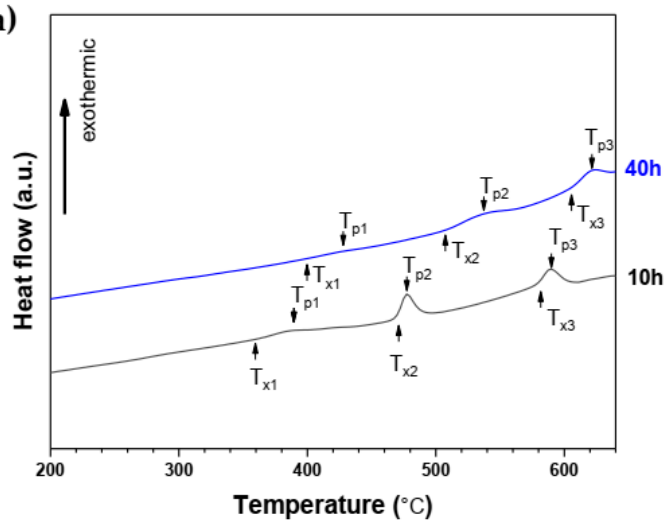

(b)

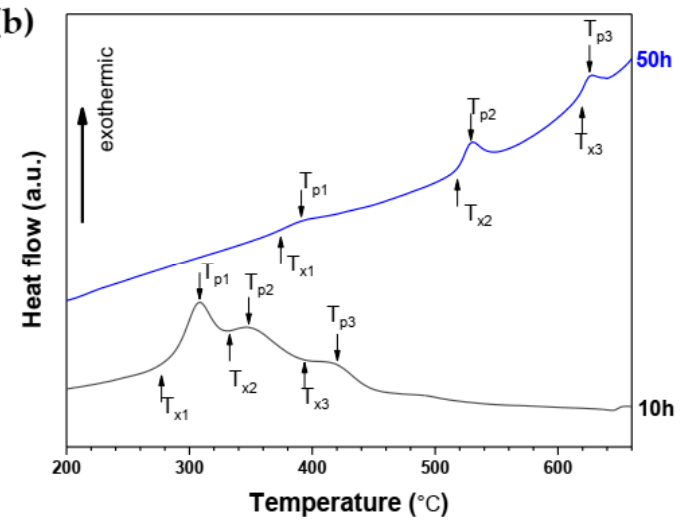

(c)

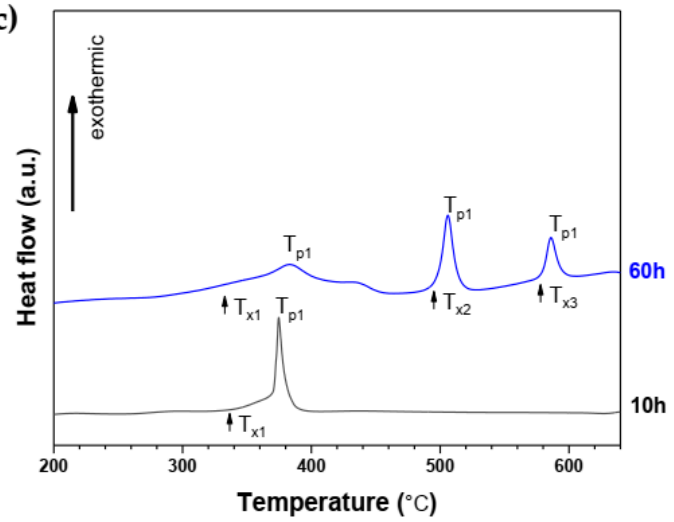

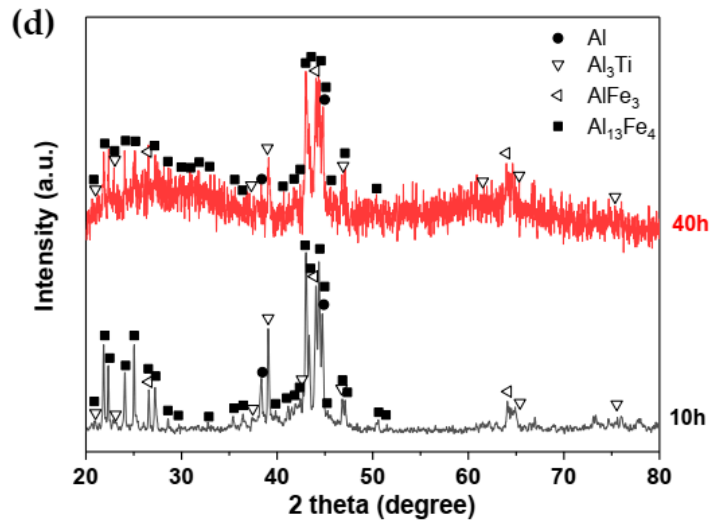
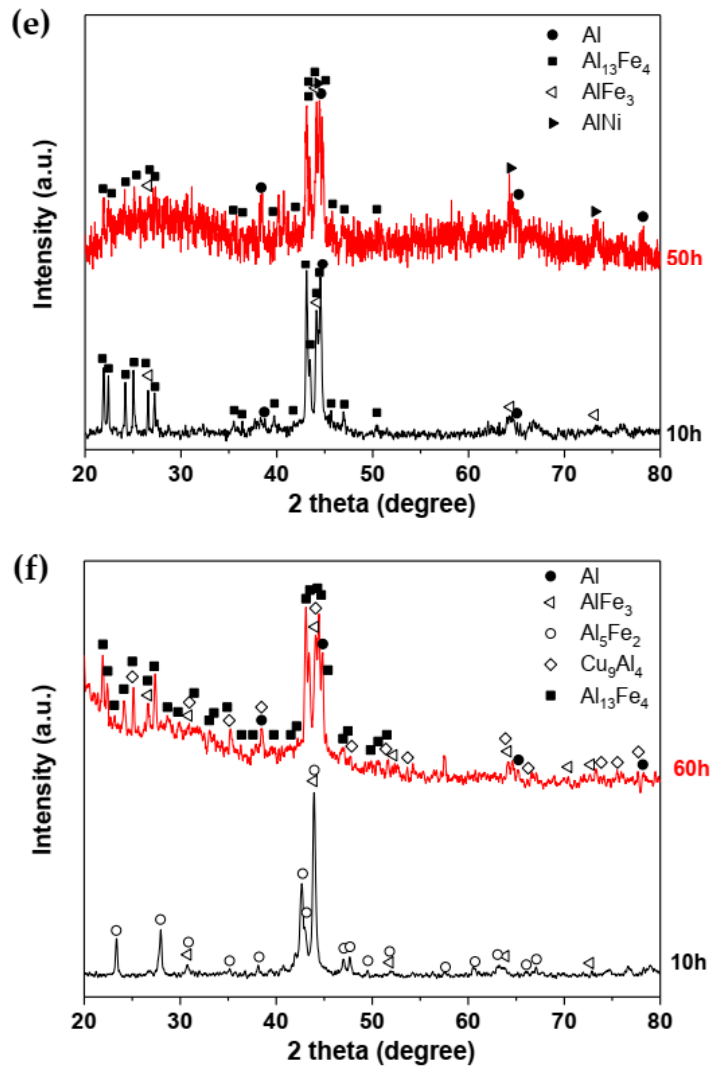

Figure 3. DSC curves of as-milled (a) $\mathrm{Al}_{82} \mathrm{Fe}_{16} \mathrm{Ti}_{2}$, (b) $\mathrm{Al}_{82} \mathrm{Fe}_{16} \mathrm{Ni}_{2}$, and (c) $\mathrm{Al}_{82} \mathrm{Fe}_{16} \mathrm{Cu}_{2}$ alloy powders and their XRD patterns after DSC examination of (d) $\mathrm{Al}_{82} \mathrm{Fe}_{16} \mathrm{Ti}_{2}$, (e) $\mathrm{Al}_{82} \mathrm{Fe}_{16} \mathrm{Ni}_{2}$, and (f) $\mathrm{Al}_{82} \mathrm{Fe}_{16} \mathrm{Cu}_{2}$ alloys. 
The thermal stability of three amorphous alloys can be explained by the binary mixing enthalpies of constituent elements listed in Table $1 . \Delta \mathrm{H}_{\text {mix }}$ between $\mathrm{Ti}, \mathrm{Ni}, \mathrm{Cu}$, and $\mathrm{Al}$ (solvent) is $-30,-22$ and $-1 \mathrm{~kJ} /$ mole, respectively. Thus, $\Delta \mathrm{H}_{\text {mix }}$ of Ti-Al was more negative than that of $\mathrm{Ni}-\mathrm{Al}$ and $\mathrm{Cu}-\mathrm{Al}$. The crystallization onset temperature of the $\mathrm{Al}_{82} \mathrm{Fe}_{16} \mathrm{Ti}_{2}$ amorphous alloy was the highest value among the three alloys. The more negative the enthalpy of mixing, the larger the atomic constraint force, resulting in a higher thermal stability. The thermal stabilities of the three alloys were in the following order: $\mathrm{Al}_{82} \mathrm{Fe}_{16} \mathrm{Ti}_{2}-\mathrm{Al}_{82} \mathrm{Fe}_{16} \mathrm{Ni}_{2}-\mathrm{Al}_{82} \mathrm{Fe}_{16} \mathrm{Cu}_{2}$. Looking into details of the other alloys in Table 2, we can see that amorphous $\mathrm{Al}_{84} \mathrm{Fe}_{16}$ composition starts crystallization at $353^{\circ} \mathrm{C}$. The substitution of $\mathrm{Fe}$ for $\mathrm{Al}$ (2 at.\%) in $\mathrm{Al}_{84} \mathrm{Fe}_{16}$, the alloy system became $\mathrm{Al}_{82} \mathrm{Fe}_{18}$ and the number of Al-Fe pairs increased from 16 to 18. The crystallization temperature of $\mathrm{Al}_{82} \mathrm{Fe}_{18}$ was raised to $375^{\circ} \mathrm{C}$. As the number of Al-Fe pairs increased, the thermal stability of $\mathrm{Al}_{82} \mathrm{Fe}_{18}$ alloy also increased. Similar to the above case, the substitution of Ti for $\mathrm{Al}(2 \mathrm{at} . \%)$ results in the crystallization onset temperature of the $\mathrm{Al}_{82} \mathrm{Fe}_{16} \mathrm{Ti}_{2}$ alloy, increasing to $398^{\circ} \mathrm{C}$. $\Delta \mathrm{H}_{\text {mix }}$ of Ti-Fe $(-17 \mathrm{~kJ} /$ mole) was more negative than that of Al-Fe $(-1 \mathrm{~kJ} / \mathrm{mole})$, which means that the GFA of the $\mathrm{Al}_{82} \mathrm{Fe}_{16} \mathrm{Ti}_{2}$ alloy can be improved more compared to that of the $\mathrm{Al}_{84} \mathrm{Fe}_{16}$ alloy. However, in the $\mathrm{Al}_{82} \mathrm{Fe}_{16} \mathrm{Ni}_{2}$ alloy, the crystallization temperature was higher than $\mathrm{Al}_{84} \mathrm{Fe}_{16}$ and lower than $\mathrm{Al}_{82} \mathrm{Fe}_{18}$ and $\mathrm{Al}_{82} \mathrm{Fe}_{16} \mathrm{Ti}_{2}$ alloys. $\Delta \mathrm{H}_{\text {mix }}$ of $\mathrm{Ni}-\mathrm{Fe}$ is $(-2 \mathrm{~kJ} / \mathrm{mole})$ was lower than $\mathrm{Al}-\mathrm{Fe}(-11 \mathrm{~kJ} / \mathrm{mole})$ and Ti-Fe $(-17 \mathrm{~kJ} / \mathrm{mole})$, which results in the lower crystallization temperature of the $\mathrm{Al}_{82} \mathrm{Fe}_{16} \mathrm{Ni}_{2}$ alloy, compared to $\mathrm{Al}_{84} \mathrm{Fe}_{16}$, $\mathrm{Al}_{82} \mathrm{Fe}_{18}$, and $\mathrm{Al}_{82} \mathrm{Fe}_{16} \mathrm{Ti}_{2}$ alloys. DSC curves of the $\mathrm{Al}_{82} \mathrm{Fe}_{16} \mathrm{Cu}_{2}$ alloy showed very broad peaks between 120 and $700{ }^{\circ} \mathrm{C}$, similar to the $\mathrm{Al}_{75} \mathrm{Fe}_{25}$ alloy, as reported in [33]. The $\mathrm{Al}_{82} \mathrm{Fe}_{16} \mathrm{Cu}_{2}$ alloy had the lowest crystallization temperature due to its partial amorphous structure. It was found that the GFA reduced with the addition of $\mathrm{Cu}$ in $\mathrm{Al}_{84} \mathrm{Fe}_{16}$ due to the positive mixing enthalpies of $\mathrm{Fe}-\mathrm{Cu}(+13 \mathrm{~kJ} / \mathrm{mole})$. The more negative the mixing enthalpy in the alloy, the more thermally stable an amorphous phase against solid solution and intermediate phase is [35]. Z. Zhang et al. investigated Al-Ni-RE (RE-La, Ce) alloys produced by arc melting, which exhibited a strong dependence on the size of the RE atom and negative mixing enthalpy between the constituent elements with the glass formation [36]. However, Al-Fe-2TM prepared by MA showed that the most important factor, decided by the GFA of the alloys, was a larger negative mixing enthalpy between the constituent elements.

Table 2. Crystallization temperatures and phase compositions of Al-Fe alloys produced by a planetary ball mill.

\begin{tabular}{|c|c|c|c|c|c|c|c|c|c|c|}
\hline \multirow{2}{*}{ Alloys } & \multirow{2}{*}{ Phase after MA } & \multicolumn{7}{|c|}{ Crystallization Temperatures, $\left({ }^{\circ} \mathrm{C}\right)$} & \multirow{2}{*}{$\begin{array}{c}\text { Crystallization } \\
\text { Phases }\end{array}$} & \multirow{2}{*}{ Ref } \\
\hline & & $T_{x 1}$ & $\mathbf{T}_{\mathrm{p} 1}$ & $T_{x 2}$ & $T_{p 2}$ & $T_{x 3}$ & $T_{p 3}$ & $T_{x 4}$ & & \\
\hline $\mathrm{Al}_{84} \mathrm{Fe}_{16}$ & amorphous & 353 & - & 450 & - & 511 & - & 590 & $\begin{array}{c}\mathrm{Al}, \mathrm{Al}_{13} \mathrm{Fe}_{4} \\
\mathrm{Al}_{6} \mathrm{Fe}\end{array}$ & {$[34]$} \\
\hline $\mathrm{Al}_{82} \mathrm{Fe}_{18}$ & amorphous & 380 & - & 491 & - & 579 & - & - & $\mathrm{Al}, \mathrm{Al}_{13} \mathrm{Fe}_{4}$ & [34] \\
\hline $\mathrm{Al}_{82} \mathrm{Fe}_{16} \mathrm{Y}_{2}$ & amorphous & 382 & - & 486 & - & 584 & - & - & $\begin{array}{c}\mathrm{Al}, \mathrm{Al}_{6} \mathrm{Fe}, \mathrm{Fe}_{4} \mathrm{Y} \\
\mathrm{Al}_{13} \mathrm{Fe}_{4} \\
\mathrm{Al},\end{array}$ & [34] \\
\hline $\mathrm{Al}_{82} \mathrm{Fe}_{16} \mathrm{Ti}_{2}$ & amorphous & 398 & 424 & 507 & 535 & 605 & 623 & - & $\begin{array}{r}\mathrm{Al}_{3} \mathrm{Ti} \\
\mathrm{AlFe}_{3} \\
\mathrm{Al}_{13} \mathrm{Fe}_{4}\end{array}$ & This work \\
\hline $\mathrm{Al}_{82} \mathrm{Fe}_{16} \mathrm{Ni}_{2}$ & amorphous & 365 & 393 & 516 & 530 & 617 & 627 & - & $\begin{array}{l}\mathrm{Al}, \mathrm{Al}_{13} \mathrm{Fe}_{4} \\
\mathrm{AlFe}_{3}, \mathrm{AlNi}\end{array}$ & This work \\
\hline $\mathrm{Al}_{82} \mathrm{Fe}_{16} \mathrm{Cu}_{2}$ & $\begin{array}{c}\text { Partly } \\
\text { amorphous }\end{array}$ & 334 & 382 & 495 & 506 & 576 & 586 & - & $\begin{array}{c}\mathrm{Al}, \mathrm{Al}_{13} \mathrm{Fe}_{4} \\
\mathrm{AlFe}_{3}, \mathrm{Al}_{5} \mathrm{Fe}_{2} \\
\mathrm{Cu}_{9} \mathrm{Al}_{4}\end{array}$ & This work \\
\hline
\end{tabular}

The phase transformation of amorphous alloy powders after DSC heating was performed by using the XRD technique. The X-ray diffraction patterns of the DSC-quenched samples for as-milled $\mathrm{Al}_{82} \mathrm{Fe}_{16} \mathrm{Ti}_{2}, \mathrm{Al}_{82} \mathrm{Fe}_{16} \mathrm{Ni}_{2}$, and $\mathrm{Al}_{82} \mathrm{Fe}_{16} \mathrm{Cu}_{2}$ alloy powders are shown in Figure 3d-f. Similar phase formations were seen in $\mathrm{Al}_{82} \mathrm{Fe}_{16} \mathrm{Ti}_{2}$ and $\mathrm{Al}_{82} \mathrm{Fe}_{16} \mathrm{Ni}_{2}$ alloys 
after being milled for 10,40 , and $50 \mathrm{~h}$. However, for $\mathrm{Al}_{82} \mathrm{Fe}_{16} \mathrm{Cu}_{2}$ alloy powder milled for $10 \mathrm{~h}$, only $\mathrm{Al}_{5} \mathrm{Fe}_{2}$ and $\mathrm{AlFe}_{3}$ were detected from XRD patterns, while higher precipitation phases of fcc- $\mathrm{Al}, \mathrm{Cu}_{9} \mathrm{Al}_{4}$, and $\mathrm{Al}_{13} \mathrm{Fe}_{4}$ could be only obtained from $\mathrm{Al}_{82} \mathrm{Fe}_{16} \mathrm{Cu}_{2}$ alloy powder milled for $60 \mathrm{~h}$.

Via the thermal effect, the glassy phase was transformed into fcc-Al and intermetallic phases. The first exothermic peak around $360-390{ }^{\circ} \mathrm{C}$ represents the precipitation of crystalline $\alpha-\mathrm{Al}$ on the $\mathrm{Al}$ matrix, which could improve the strength of the alloy and increase material performance [24]. The next two exothermal peaks mark the appearance of intermetallic phases, such as $\mathrm{Al}_{13} \mathrm{Fe}_{4}, \mathrm{AlFe}_{3}$, and $\mathrm{Al}_{3} \mathrm{Ti}$ for the $\mathrm{Al}_{82} \mathrm{Fe}_{16} \mathrm{Ti}_{2}$ alloy; $\mathrm{AlNi}$, $\mathrm{AlFe}_{3}$, and $\mathrm{Al}_{13} \mathrm{Fe}_{4}$ for $\mathrm{Al}_{82} \mathrm{Fe}_{16} \mathrm{Ni}_{2}$ alloy; and $\mathrm{Cu}_{9} \mathrm{Al}_{4}, \mathrm{Al}_{5} \mathrm{Fe}_{2}, \mathrm{AlFe}_{3}$, and $\mathrm{Al}_{13} \mathrm{Fe}_{4}$ for the $\mathrm{Al}_{82} \mathrm{Fe}_{16} \mathrm{Cu}_{2}$ alloy. These intermetallic phases have negative formation enthalpy as the Miedema calculation [37]. The formation enthalpies of $\mathrm{Al}_{13} \mathrm{Fe}_{4}, \mathrm{AlFe}_{3}, \mathrm{Al}_{3} \mathrm{Ti}, \mathrm{Al}_{5} \mathrm{Fe}_{2}, \mathrm{AlNi}$, and $\mathrm{Cu}_{9} \mathrm{Al}_{4}$ are $-18.052,-22.078,-39.02,-21.855,-48.424$, and $-13.104 \mathrm{~kJ} / \mathrm{mole}$, respectively. A mixture of $\mathrm{Al}_{13} \mathrm{Fe}_{4}, \mathrm{Al}_{6} \mathrm{Fe}, \mathrm{Fe}_{4} \mathrm{Y}$, and $\mathrm{Al}$ phases was reported as a crystallization product after heating the amorphous $\mathrm{Al}_{82} \mathrm{Fe}_{16} \mathrm{Y}_{2}$ alloy to $700{ }^{\circ} \mathrm{C}$ in the same calorimeter used in previous our work [34]. It can be realized that, for amorphous alloys with a small amount of the different transition elements or rare-earth elements obtained in the same mills, dissimilar phases crystallized during analogous heat treatment. Thus, the crystallization process of amorphous alloys with the same milling parameters can be influenced by composition. This indicates that these Al-based amorphous alloys (produced in the same mills) actually differ. The refined lattice parameters of the DSC-quenched samples were calculated using Profex software packages. It is very interesting that two $\mathrm{Al}_{13} \mathrm{Fe}_{4}$ and $\mathrm{AlFe}_{3}$ intermetallic phases were precipitated from the amorphous phase of all three alloys. Considering this, milling of these alloys resulted in the formation of solid solutions of $\alpha-\mathrm{Al}(\mathrm{Fe})$ and $\alpha-\mathrm{Fe}(\mathrm{Al})$, then transformed to the $\mathrm{AlFe}_{3}$ intermetallic phase. Additionally, in the opposite process, the crystallization of the amorphous phase, the $\mathrm{AlFe}_{3}$ intermetallic phase was also produced. It is noticeable that the $\mathrm{AlFe}_{3}$ phase had high negative formation enthalpy of $-22.078 \mathrm{~kJ} / \mathrm{mole}$, so it was easy to form during crystallization. A slight difference in lattice parameters for $\mathrm{Al}_{13} \mathrm{Fe}_{4}$ and $\mathrm{AlFe}_{3}$ intermetallic phases can be seen in Table 3. A lattice expansion is observed as a result of disordering of the lattice when the iron diffusion into the aluminum lattice formed intermetallic phases during crystallization. The lattice constant of fcc-Al as a sample after DSC was similar to that in \#PDF 04-0787.

Table 3. Refined lattice parameters of crystallization phases formed from DSC-quenched $\mathrm{Al}_{82} \mathrm{Fe}_{16} \mathrm{Ti}_{2}, \mathrm{Al}_{82} \mathrm{Fe}_{16} \mathrm{Ni}_{2}$, and $\mathrm{Al}_{82} \mathrm{Fe}_{16} \mathrm{Cu}_{2}$ alloy powders.

\begin{tabular}{|c|c|c|c|c|c|c|c|}
\hline Sample & Phase & $\begin{array}{l}\text { ICDD/JCPDS } \\
\text { ID * }\end{array}$ & $\begin{array}{c}\text { Lattice } \\
\text { Parameters } \\
\text { (nm) }\end{array}$ & CIF ID ** & \multicolumn{2}{|c|}{$\begin{array}{l}\text { Refined Lattice Parameters } \\
\text { (nm) }\end{array}$} & $\begin{array}{c}\text { Formation } \\
\text { Enthalpy, } \\
\mathrm{kJ} / \mathrm{mol}\end{array}$ \\
\hline $\begin{array}{c}\mathbf{A l}_{\mathbf{8 2}} \mathbf{F e}_{\mathbf{1 6}} \mathbf{T i}_{\mathbf{2}} \\
\text { Cubic } \\
F m-3 m(225)\end{array}$ & $\mathrm{Al}$ & 04-0787 & $a=0.40494$ & & $\begin{array}{l}\text { MA } 10 \mathrm{~h} \\
a=0.40584\end{array}$ & $\begin{array}{l}\text { MA } 40 \mathrm{~h} \\
a=0.4049\end{array}$ & \\
\hline $\begin{array}{l}\text { Monoclinic } \\
\text { C2/m (12) }\end{array}$ & $\mathrm{Al}_{13} \mathrm{Fe}_{4}$ & 29-0042 & $\begin{array}{c}a=1.5489 \\
b=0.8083 \\
c=1.2476 \\
\beta=107.7\end{array}$ & ICSD_151129 & $\begin{array}{l}a=1.5498 \\
b=0.8089 \\
c=1.2501 \\
\beta=107.93\end{array}$ & $\begin{array}{l}a=1.5511 \\
b=0.8092 \\
c=1.2527 \\
\beta=108.15\end{array}$ & -18.052 \\
\hline $\begin{array}{c}\text { Cubic } \\
\text { Fm-3m (225) }\end{array}$ & $\mathrm{AlFe}_{3}$ & $45-1203$ & $a=0.57934$ & mp-2018 & $a=0.5765$ & $a=0.5803$ & -22.078 \\
\hline $\begin{array}{l}\text { Tetragonal } \\
\text { I4/mmm (139) }\end{array}$ & $\mathrm{Al}_{3} \mathrm{Ti}$ & $37-1449$ & $\begin{array}{l}a=0.38537 \\
c=0.85839\end{array}$ & mp-542915 & $\begin{array}{l}a=0.3851 \\
c=0.8602\end{array}$ & $\begin{array}{l}a=0.3852 \\
c=0.8609\end{array}$ & -39.020 \\
\hline
\end{tabular}


Table 3. Cont.

\begin{tabular}{|c|c|c|c|c|c|c|c|}
\hline Sample & Phase & $\begin{array}{l}\text { ICDD/JCPDS } \\
\text { ID * }\end{array}$ & $\begin{array}{c}\text { Lattice } \\
\text { Parameters } \\
\text { (nm) }\end{array}$ & CIF ID ** & \multicolumn{2}{|c|}{$\begin{array}{l}\text { Refined Lattice Parameters } \\
\qquad(\mathrm{nm})\end{array}$} & $\begin{array}{c}\text { Formation } \\
\text { Enthalpy, } \\
\text { kJ/mol }\end{array}$ \\
\hline $\mathrm{Al}_{82} \mathrm{Fe}_{16} \mathrm{Ni}_{2}$ & & & & & MA $10 \mathrm{~h}$ & MA $50 \mathrm{~h}$ & - \\
\hline $\begin{array}{c}\text { Cubic } \\
\text { Fm-3m (225) }\end{array}$ & $\mathrm{Al}$ & - & $a=0.40494$ & - & $a=0.4053$ & $a=0.4049$ & - \\
\hline $\begin{array}{l}\text { Monoclinic } \\
\text { C2/m (12) }\end{array}$ & $\mathrm{Al}_{13} \mathrm{Fe}_{4}$ & 29-0042 & $\begin{array}{l}a=1.5489 \\
b=0.8083 \\
c=1.2476 \\
\beta=107.7\end{array}$ & ICSD_151129 & $\begin{array}{l}a=1.5462 \\
b=0.8118 \\
c=1.2489 \\
\beta=107.81\end{array}$ & $\begin{array}{l}a=1.5495 \\
b=0.8084 \\
c=1.2491 \\
\beta=107.89\end{array}$ & - \\
\hline $\begin{array}{c}\text { Cubic } \\
\text { Fm-3m (225) }\end{array}$ & $\mathrm{AlFe}_{3}$ & $50-0955$ & $a=0.58152$ & mp-2018 & $a=0.5747$ & $a=0.5803$ & - \\
\hline $\mathrm{Al}_{82} \mathrm{Fe}_{16} \mathrm{Cu}_{2}$ & & & & & MA $10 \mathrm{~h}$ & MA $60 \mathrm{~h}$ & - \\
\hline $\begin{array}{c}\text { Cubic } \\
\text { Fm-3m (225) }\end{array}$ & $\mathrm{Al}$ & - & $a=0.40494$ & - & - & $a=0.4050$ & - \\
\hline $\begin{array}{l}\text { Monoclinic } \\
C 2 / m(12)\end{array}$ & $\mathrm{Al}_{13} \mathrm{Fe}_{4}$ & 29-0042 & $\begin{array}{l}a=1.5489 \\
b=0.8083 \\
c=1.2476 \\
\beta=107.7\end{array}$ & ICSD_151129 & - & $\begin{array}{l}a=1.5515 \\
b=0.8094 \\
c=1.2521 \\
\beta=107.86\end{array}$ & - \\
\hline $\begin{array}{c}\text { Cubic } \\
\text { Fm-3m (225) }\end{array}$ & $\mathrm{AlFe}_{3}$ & 50-0955 & $a=0.58152$ & mp-2018 & $a=0.5803$ & $a=0.5771$ & - \\
\hline $\begin{array}{l}\text { Orthorhombic } \\
\text { Cmcm (63) }\end{array}$ & $\mathrm{Al}_{5} \mathrm{Fe}_{2}$ & $47-1435$ & $\begin{array}{l}a=0.76486 \\
b=0.64131 \\
c=0.42165\end{array}$ & COD_2101159 & $\begin{array}{l}a=0.7620 \\
b=0.6424 \\
c=0.4204\end{array}$ & - & -21.855 \\
\hline $\begin{array}{c}\text { Cubic } \\
P-43 m(215)\end{array}$ & $\mathrm{Cu}_{9} \mathrm{Al}_{4}$ & 24-0003 & $a=0.87027$ & $m p-593$ & - & $a=0.8789$ & -13.104 \\
\hline
\end{tabular}

$*$ id of materials taken from ICDD/JCPDS were indexed in MDI Jade 6.5. ** id of materials were taken from materialsproject.org, www.crystallography.net (accessed on 7 August 2020), and icsd.products.fiz-karlsruhe.de, which were then converted to structure files used in Profex software.

\section{Conclusions}

In the present study, the thermal stability of mechanically alloying powders increased in the order of $\mathrm{Al}_{82} \mathrm{Fe}_{16} \mathrm{Cu}_{2}, \mathrm{Al}_{82} \mathrm{Fe}_{16} \mathrm{Ni}_{2}$, and $\mathrm{Al}_{82} \mathrm{Fe}_{16} \mathrm{Ti}_{2}$ alloys. The crystallization in $\mathrm{Al}_{82} \mathrm{Fe}_{16} \mathrm{Ti}_{2}, \mathrm{Al}_{82} \mathrm{Fe}_{16} \mathrm{Ni}_{2}$, and $\mathrm{Al}_{82} \mathrm{Fe}_{16} \mathrm{Cu}_{2}$ started at: 398,365 , and $334{ }^{\circ} \mathrm{C}$, respectively. For ternary $\mathrm{Al}-\mathrm{Fe}-\mathrm{TM}\left(\mathrm{TM}: \mathrm{Ti}, \mathrm{Ni}, \mathrm{Cu}\right.$ ) alloys, $\Delta \mathrm{H}_{\text {mix }}$ was the main factor deciding the amorphization process. The larger the negative mixing enthalpy between binary elements in the alloys, the faster the amorphization process was. $\mathrm{Al}_{82} \mathrm{Fe}_{16} \mathrm{Ti}_{2}$ amorphous alloy had the highest glass-forming ability and thermal stability among the three alloys. A considerably lower thermal stability of $\mathrm{Al}_{82} \mathrm{Fe}_{16} \mathrm{Cu}_{2}$ than the other alloys may arise from a system with a positive heat of mixing. A larger negative mixing enthalpy between the constituent elements was the key factor, which decided the GFA of amorphous alloys. The crystallization of these alloys occurred during the DSC process, with the transformation of the amorphous phase into fcc-Al and intermetallic phases. The diffusion of $\mathrm{Fe}$ in $\mathrm{Al}$ lattice to produce intermetallic phase $\mathrm{Al}_{13} \mathrm{Fe}_{4}$ and $\mathrm{AlFe}_{3}$ resulted in the slightly different lattice parameters compared to standard phases. The GFA and crystallization in Al-Fe-2TM metallic glasses were much more sensitive to minor alloying elements.

Author Contributions: Conceptualization, N.H.V., N.T.H.O., and D.N.B.; methodology, investigation, and validation, D.N.B. and Q.H.T.N.; software, visualization, and validation, D.D.D., Q.H.T.N. and N.H.V.; writing—original draft preparation, review, and editing, N.T.H.O., D.D.D. and N.H.V. All authors have read and agreed to the published version of the manuscript.

Funding: This research is funded by the Hanoi University of Science and Technology (HUST) under project number T2020-TĐ-007.

Institutional Review Board Statement: Not applicable.

Informed Consent Statement: Not applicable. 
Data Availability Statement: Data is contained within the article.

Conflicts of Interest: The authors declare no conflict of interest.

\section{References}

1. He, Y.; Poon, S.J.; Shiflet, G.J. Synthesis and Properties of Metallic Glasses That Contain Aluminum. Science 1988, 241, 1640. [CrossRef]

2. He, Y.; Shiflet, G.J.; Poon, S.J. Synthesis and properties of aluminum-based metallic glasses containing rare earths. J. Alloys Compd. 1994, 207-208, 349-354. [CrossRef]

3. Miller, M.K.; Liaw, P. Bulk Metallic Glasses; Springer: New York, NY, USA, 2008; p. 256.

4. Suryanarayana, C.; Inoue, A. Metallic Glasses. In Ullmann's Encyclopedia of Industrial Chemistry; Wiley-VCH Verlag GmbH: Weinheim, Germany, 2012. [CrossRef]

5. Eckert, J.; Calin, M.; Yu, P.; Zhang, L.C.; Scudino, S.; Duhamel, C. Al-based alloys containing amorphous and nanostructured phases. Rev. Adv. Mater. Sci. 2008, 18, 169-172.

6. Seikh, A.H.; Baig, M.; Singh, J.K.; Mohammed, J.A.; Luqman, M.; Abdo, H.S.; Khan, A.R.; Alharthi, N.H. Microstructural and Corrosion Characteristics of Al-Fe Alloys Produced by High-Frequency Induction-Sintering Process. Coatings 2019, 9, 686. [CrossRef]

7. Krasnowski, M.; Kulik, T. Nanocrystalline and amorphous Al-Fe alloys containing 60-85\% of Al synthesised by mechanical alloying and phase transformations induced by heating of milling products. Mater. Chem. Phys. 2009, 116, 631-637. [CrossRef]

8. Inoue, A.; Kimura, H. Fabrications and mechanical properties of bulk amorphous, nanocrystalline, nanoquasicrystalline alloys in aluminum-based system. J. Light Met. 2001, 1, 31-41. [CrossRef]

9. Suryanarayana, C. Mechanical Alloying: A Novel Technique to Synthesize Advanced Materials. Research 2019, $2019,4219812$. [CrossRef]

10. Inoue, A.; Kong, F.; Zhu, S.; Liu, C.; Al-Marzouki, F. Development and Applications of Highly Functional Al-based Materials by Use of Metastable Phases. Mater. Res. 2015, 18. [CrossRef]

11. Zhang, Z.; Witkin, D.; Lavernia, E.J. Crystallization behavior of a gas atomized $\mathrm{Al}_{85} \mathrm{Ni}_{10} \mathrm{La}_{5}$ amorphous alloy. J. Non-Cryst. Solids 2005, 351, 1646-1652. [CrossRef]

12. Viet, N.H.; Oanh, N.T.; Kim, J.-S.; Jorge, A.M. Crystallization Kinetics and Consolidation of $\mathrm{Al}_{82} \mathrm{La}_{10} \mathrm{Fe}_{4} \mathrm{Ni}_{4} \mathrm{Glassy} \mathrm{Alloy}$ Powder by Spark Plasma Sintering. Metals 2018, 8, 812. [CrossRef]

13. Kim, H.S.; Hong, S.I.; Kato, H.; Inoue, A. Strengthening Mechanisms in Al-Based and Zr-Based Amorphous Nanocomposites. Mater. Trans. 2002, 43, 2026-2030. [CrossRef]

14. Roy, D.; Chakravarty, D.; Mitra, R.; Manna, I. Effect of sintering on microstructure and mechanical properties of nano-TiO 2 dispersed $\mathrm{Al}_{65} \mathrm{Cu}_{20} \mathrm{Ti}_{15}$ amorphous/nanocrystalline matrix composite. J. Alloys Compd. 2008, 460, 320-325. [CrossRef]

15. Bassim, N.; Kiminami, C.S.; Kaufman, M.J.; Oliveira, M.F.; Perdigao, M.N.R.V.; Botta Filho, W.J. Crystallization behavior of amorphous $\mathrm{Al}_{84} \mathrm{Y}_{9} \mathrm{Ni}_{5} \mathrm{CO}_{2}$ alloy. Mater. Sci. Eng. A 2001, 304-306, 332-337. [CrossRef]

16. Wang, J.Q.; Chang, X.C.; Hou, W.L.; Hu, Z.Q. Crystallization behaviour of Al-based amorphous alloy and nanocomposites by rapid quenching. Philos. Mag. Lett. 2000, 80, 349-357. [CrossRef]

17. Nguyen, V.H.; Nguyen, O.T.H.; Dudina, D.V.; Le, V.V.; Kim, J.-S. Crystallization Kinetics of Al-Fe and Al-Fe-Y Amorphous Alloys Produced by Mechanical Milling. J. Nanomater. 2016, 2016, 1909108. [CrossRef]

18. Weeber, A.W.; Bakker, H. Amorphization by ball milling. A review. Phys. B Condens. Matter 1988, 153, 93-135. [CrossRef]

19. Lü, L.; Lai, M.O. Mechanical Alloying, 1st ed.; Springer: Boston, MA, USA, 1998; p. 276. [CrossRef]

20. Suryanarayana, C. Mechanical Alloying and Milling, 1st ed.; CRC Press: Boca Raton, FL, USA, 2004; p. 488. [CrossRef]

21. Surreddi, K.B.; Scudino, S.; Nguyen, H.V.; Nikolowski, K.; Stoica, M.; Sakaliyska, M.; Kim, J.S.; Gemming, T.; Vierke, J.; Wollgarten, M.; et al. Spark plasma sintering of gas atomized $\mathrm{Al}_{87} \mathrm{Ni}_{8} \mathrm{La}_{5}$ amorphous powder. J. Phys. Conf. Ser. 2009, 144, 012079. [CrossRef]

22. Nguyen, H.-V.; Kim, J.-S.; Kwon, Y.-S.; Kim, J.-C. Amorphous Ti-Cu-Ni-Al alloys prepared by mechanical alloying. J. Mater. Sci. 2009, 44, 2700-2704. [CrossRef]

23. Liu, X.; Wang, X.; Si, Y.; Han, F. Glass-Forming Ability and Thermal Properties of $\mathrm{Al}_{70} \mathrm{Fe}_{12.5} \mathrm{~V}_{12.5} \mathrm{X}_{5}(\mathrm{X}=\mathrm{Zr}$, Nb, Ni) Amorphous Alloys via Minor Alloying Additions. Nanomaterials 2021, 11, 488. [CrossRef] [PubMed]

24. Babilas, R.; Spilka, M.; Młynarek, K.; Łoński, W.; Łukowiec, D.; Radoń, A.; Kądziołka-Gaweł, M.; Gębara, P. Glass-Forming Ability and Corrosion Resistance of $\mathrm{Al}_{88} \mathrm{Y}_{8-\mathrm{x}} \mathrm{Fe}_{4+\mathrm{x}}(\mathrm{x}=0,1,2$ at.\%) Alloys. Materials 2021, 14, 1581. [CrossRef]

25. Oleszak, D. Mechanical alloying-A novel method for synthesis and processing of materials. Acta Phys. Pol. A 1999, 96, 101-112. [CrossRef]

26. Shan, L.; Wang, X.; Wang, Y. Extension of Solid Solubility and Structural Evolution in Nano-Structured Cu-Cr Solid Solution Induced by High-Energy Milling. Materials 2020, 13, 5532. [CrossRef] [PubMed]

27. Suñol, J.-J. Mechanical Alloying: Processing and Materials. Metals 2021, 11, 798. [CrossRef]

28. Oanh, N.T.H.; Viet, N.H.; Dudina, D.V.; Jorge, A.M.; Kim, J.-S. Structural characterization and magnetic properties of $\mathrm{Al}_{82} \mathrm{Fe}_{16} \mathrm{TM}_{2}$ (TM: Ti, Ni, Cu) alloys prepared by mechanical alloying. J. Non-Cryst. Solids 2017, 468, 67-73. [CrossRef]

29. Doebelin, N.; Kleeberg, R. Profex: A graphical user interface for the Rietveld refinement program BGMN. J. Appl. Cryst. 2015, 48, 1573-1580. [CrossRef] 
30. Takeuchi, A.; Inoue, A. Classification of Bulk Metallic Glasses by Atomic Size Difference, Heat of Mixing and Period of Constituent Elements and Its Application to Characterization of the Main Alloying Element. Mater. Trans. 2005, 46, 2817-2829. [CrossRef]

31. Takeuchi, A.; Inoue, A. Analyses of characteristics of atomic pairs in ferrous bulk metallic glasses using classification of bulk metallic glasses and pettifor map. J. Optoelectron. Adv. Mater. 2006, 8, 1679-1684.

32. Suryanarayana, C.; Inoue, A. Iron-based bulk metallic glasses. Int. Mater. Rev. 2013, 58, 131-166. [CrossRef]

33. Urban, P.; Cuevas, F.G.; Montes, J.M.; Cintas, J. Solid state amorphization in the Al-Fe binary system during high energy milling. AIP Conf. Proc. 2013, 1569, 476-479. [CrossRef]

34. Nguyen, H.V.; Oanh, N.T.H.; Quynh, P.N.D.; Lap, T.Q.; Kim, J.S. Thermal Stability of Amorphous Al-Fe-Y Prepared by Mechanical Alloying. Mater. Sci. Forum 2015, 804, 271-274. [CrossRef]

35. Takeuchi, A.; Inoue, A. Calculations of Mixing Enthalpy and Mismatch Entropy for Ternary Amorphous Alloys. Mater. Trans. JIM 2000, 41, 1372-1378. [CrossRef]

36. Zhang, Z.; Xiong, X.Z.; Zhou, W.; Li, J.F. Influence of substitution of La by Ce on the glass forming ability and crystallization behavior of Al-Ni-La alloys. J. Alloys Compd. 2013, 576, 181-186. [CrossRef]

37. Zhang, R.F.; Zhang, S.H.; He, Z.J.; Jing, J.; Sheng, S.H. Miedema Calculator: A thermodynamic platform for predicting formation enthalpies of alloys within framework of Miedema's Theory. Comput. Phys. Commun. 2016, 209, 58-69. [CrossRef] 